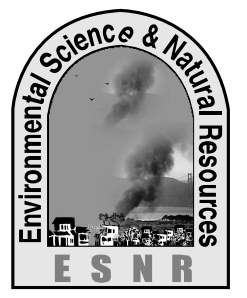

J. Environ. Sci. \& Natural Resources, 5(1): 295-299, 2012

ISSN 1999-7361

\title{
Urea Super Granule: A Good Source of Nitrogen on Growth Yield and Profitability of Cabbage in Sylhet
} M. M. R. Sarker ${ }^{1}$, M. R. Shaheb ${ }^{2}$ and M. I. Nazrul ${ }^{2}$

${ }^{1}$ On-Farm Research Division, Bangladesh Agricultural Research Institute, Gazipur

${ }^{2}$ On-Farm Research Division, Bangladesh Agricultural Research Institute, Sylhet

\begin{abstract}
An experiment was conducted in Sylhet under AEZ-20 (Eastern Surma-Kushiyara Floodplain) during 2007-08 and 2008-09 to find out the effect of Urea Super Granule (USG) on cabbage. There were five treatments viz. $\mathrm{T}_{1}$ : recommended nitrogen (N) dose as prilled urea (PU), $\mathrm{T}_{2}$ : recommended $\mathrm{N}$ dose as $\mathrm{USG}, \mathrm{T}_{3}: 10 \%$ less than recommended dose of $\mathrm{N}$ as $\mathrm{USG}, \mathrm{T}_{4}: 20 \%$ less than recommended dose of $\mathrm{N}$ as USG, and $\mathrm{T}_{5}$ : farmers practice (average of 20 farmers $\mathrm{N}$ dose used as PU) used in the experiment. Results revealed that yield of cabbage increased significantly due to application of USG over PU. The highest head yield of cabbage 92.04 and $91.36 \mathrm{t} \mathrm{ha}^{-1}$ were obtained from the USG (recommended dose) in 2007-08 and 2008-09, respectively which was statistically similar with USG $10 \%$ less than recommended dose $\left(84.78 \mathrm{t} \mathrm{ha}^{-1}\right)$ instead of traditional PU. The treatments $\mathrm{T}_{3}$ and $\mathrm{T}_{4}$ were found more effective over PU, and $\mathrm{N}$ loss was also minimum than that of prilled urea where $10-20 \% \mathrm{~N}$ fertilizer could be saved by using USG instead of traditional PU. Regarding economic analysis, the higher returns were also obtained from the treatment $T_{2}$ which was more profitable in terms of higher gross returns as well as Benefit Cost Ratio (BCR).
\end{abstract}

Key words: BCR, Cabbage, Head yield, Prilled urea, USG

\section{Introduction}

Cabbage (Brassica campestris var. capitata) is a hardy and cruciferous vegetable that grows well in fertile soils. Cabbage is regarded as a good source of vitamins, high in beta-carotene and fiber. Other substantial nutrients in a half cup cooked cabbage contains calories 16, dietary fiber $2.9 \mathrm{~g}$, carbohydrates $3.6 \mathrm{mg}$ and vitamin C $18.2 \mathrm{mg}$. Cabbage recently has been shown to have diseasepreventive properties as well. Bangladesh's agriculture is affected by diversified unfavorable ecological conditions. So, judicious husbandry or utilization of the diverse ecosystems and or development of eco-friendly agronomic technology help in maintaining soil fertility and also can boost up crop production in Bangladesh. Nitrogen $(\mathrm{N})$ is an important plant nutrient and is the most limiting one due to its high mobility and different types of losses (Zaman et al., 1993). The farmers of Bangladesh usually use prilled urea (PU) for cultivation of crops. To improve fertilizer use efficiency, different types of fertilizer materials are becoming available day by day. Urea Super Granule (USG) is one of the nitrogenous fertilizers that is now available in our country and the farmers are using it for Boro rice and banana cultivation (Nazrul et al., 2007). It was found that USG as an alternative source of $\mathrm{N}$ than PU in terms of efficiency in wetland rice (Bhuiyan et al., 1991; De Datta and Crasswell, 1982; Eusuf et al., 1993 and 1995). BRRI (1988) reported the superiority of USG over PU in their research. The loss of $\mathrm{N}$ by leaching and volatilization is minimal in USG and it supplies more $\mathrm{N}$ to crops than PU. Besides boro rice, this USG is used by farmers in some part of the country for upland vegetables crops like tomato, cabbage, broccoli, papaya, banana etc (Nazrul et al., 2006). But they generally use higher doses of $\mathrm{N}$ as normal PU with other fertilizers. The volatilization loss of PU is very high and farmers lose a huge amount of money for $\mathrm{N}$ fertilizer. To control this loss, USG application may be a good option to minimize production cost as well as to increase yield. Crasswell and De Datta (1980) reported that urea applied in the soil by broadcast method causes loss up to $50 \%$, while the point placement of USG in $10 \mathrm{~cm}$ depth showed negligible loss. Nazrul et al. (2007) reported that $5-8 \mathrm{~cm}$ depth placement of USG in cabbage cultivation could be saved $20 \% \mathrm{~N}$ than PU. Savant $e t$ al. (1991) observed that $8-10 \mathrm{~cm}$ depth of placement of USG applied in rice field could be saved $30 \% \mathrm{~N}$ than PU. It was observed that $10 \%$ less than recommended dose of $\mathrm{N}$ as USG produced more tuber and economic return than recommended PU (Rahman et al., 2004). Cabbage is grown in upland as well as medium land in Sylhet region and the cultivation is increasing day by day due to its high profitability. The efficiency of USG for cabbage in Sylhet region is still not verified. Therefore, it is needed to evaluate the performance of USG on different upland vegetable crops in AEZ-20 (Eastern Surma-Kushiyara Floodplain). So, the present study was undertaken to verify the effect of USG on the growth and yield of cabbage and to compare the effectiveness of USG over existing practice (PU) along with to observe the farmers perception on USG application on cabbage. 


\section{Materials and Methods}

The experiment was carried out at Sylhet under AEZ20 during the two consecutive years of 2007-08 and 2008-09 to evaluate the effect of USG application on the growth and yield of cabbage. The experiment included 5 treatments viz. $\mathrm{T}_{1}$ : recommended $\mathrm{N}$ dose as $\mathrm{PU}, \mathrm{T}_{2}$ : recommended $\mathrm{N}$ dose as USG, $\mathrm{T}_{3}: 10 \%$ less than recommended dose of $\mathrm{N}$ as USG, $\mathrm{T}_{4}: 20 \%$ less than recommended dose of $\mathrm{N}$ as USG, and $\mathrm{T}_{5}$ : farmers practices (average of 20 farmers $\mathrm{N}$ dose used as PU). To know the nutrient status of the experimental soil, a composite soil sample $(0-15 \mathrm{~cm}$ depth) was collected and analyzed it at Soil Resources and Development Institute (SRDI) laboratory, Sylhet. The physical and chemical properties of experimental soil are presented in Table 1.

Table 1. Physical and chemical properties of the experimental soil

\begin{tabular}{|l|c|c|c|c|c|c|c|}
\hline Elements & $\begin{array}{c}\mathrm{N} \\
\%\end{array}$ & $\begin{array}{c}\mathrm{P}(\mu \mathrm{g} / \mathrm{g} \\
\text { soil })\end{array}$ & $\begin{array}{c}\mathrm{K}(\mathrm{m} . \mathrm{eq} \\
/ 100 \mathrm{~g} \text { soil })\end{array}$ & $\begin{array}{c}\mathrm{S}(\mu \mathrm{g} / \mathrm{g} \\
\text { soil })\end{array}$ & $\begin{array}{c}\mathrm{Zn}(\mu \mathrm{g} / \mathrm{g} \\
\text { soil })\end{array}$ & $\begin{array}{c}\mathrm{B}(\mu \mathrm{g} / \mathrm{g} \\
\text { soil })\end{array}$ & $\mathrm{pH}$ \\
\hline Soil test Value & 0.09 & 11.71 & 0.11 & 9.25 & 1.59 & 0.08 & 5.38 \\
\hline Critical limit & 0.12 & 10.00 & 0.12 & 10.00 & 0.60 & 0.2 & - \\
\hline Interpretation & low & optimum & high & high & medium & medium & acidic \\
\hline
\end{tabular}

The experiment was laid out in a Randomized Complete Block Design (RCBD) with six replications. According to soil analysis data, the doses of different plant nutrients were calculated by using fertilizer recommendation guide 2005 (BARC, 2005) and the doses of different fertilizers are given in
Table 2. The unit plot size was $6 \mathrm{~m} \times 5 \mathrm{~m}$ and plant spacing was $75 \mathrm{~cm} \times 60 \mathrm{~cm}$. Twenty five days old seedlings of cabbage (var. Atlas-70) were transplanted on 22-25 November for both the years 2007-08 and 2008-09.

Table 2. Fertilizer (nutrients) doses of different treatments for cultivation of Cabbage

\begin{tabular}{|c|c|c|c|c|c|c|c|}
\hline \multirow[t]{2}{*}{ Treatments } & \multicolumn{6}{|c|}{ Nutrients $\left(\mathrm{Kgha}^{-1}\right)$} & \multirow[t]{2}{*}{$\mathrm{CD}\left(\mathrm{Kgha}^{-1}\right)$} \\
\hline & $\mathrm{N}$ & $\mathrm{P}$ & $\mathrm{K}$ & $\mathrm{S}$ & $\mathrm{Zn}$ & B & \\
\hline $\mathrm{T}_{1}$ & 160 & 37 & 56 & 17 & 1 & 1 & 4000 \\
\hline$T_{2}$ & 160 & 37 & 56 & 17 & 1 & 1 & 4000 \\
\hline$T_{3}$ & 144 & 37 & 56 & 17 & 1 & 1 & 4000 \\
\hline $\mathrm{T}_{4}$ & 128 & 37 & 56 & 17 & 1 & 1 & 4000 \\
\hline $\mathrm{T}_{5}$ & 140 & 30 & 50 & 20 & 0 & 0 & 5000 \\
\hline
\end{tabular}

All fertilizers and $13^{\mathrm{rd}}$ of MoP were applied during the final land preparation except PU and USG and mixed thoroughly with soil. USG was applied followed by Nazrul et al., 2006 [15 Days After Transplanting (DAT) as ring method, $10 \mathrm{~cm}$ apart from plant stalk, and $8 \mathrm{~cm}$ depth covering with soil]. PU was applied as ring method in three equal splits one each at 10, 20 and $30 \mathrm{DAT}$, respectively. The rest $2 /{ }^{\text {rd }}$ of MoP were applied in two times viz: 20 DAT and at the heading stage following ring method for all the treatments. But in farmers practice, all fertilizers were applied during the final land preparation. Intercultural operations viz. weeding, irrigation and spraying insecticides were done as and when required in order to support normal cabbage growth and development. The crop was harvested after full maturity. The data on head yield and different yield components of cabbage were recorded from 5 randomly selected plants in each plot and then plot wise yield was measured. The collected data were analyzed statistically following the ANOVA technique with the help of MSTAT-C software. The mean differences among the treatment means were adjudged by Least Square Difference (LSD) (Gomez and Gomez, 1984). Cost and return analysis of different treatments were done for Benefit Cost Ratio (BCR). Gross return was calculated from two years mean yield of Cabbage.

\section{Results and Discussion}

The results revealed that head yield and yield components of cabbage showed significant variations due to application of USG over PU (Table 3 and 4). The different parameters are discussed below.

\section{Plant height of cabbage}

In 2007-08, the highest plant height $(35.01 \mathrm{~cm})$ was found with the recommended $\mathrm{N}$ dose used as USG followed by USG $<10 \%$ recommended dose of N. The lowest plant height $(27.03 \mathrm{~cm})$ was recorded from 
farmers' practice. On the other hand, in 2008-09, the highest plant height $(33.76 \mathrm{~cm})$ was gained with the recommended $\mathrm{N}$ dose applied as USG followed by $\mathrm{USG}<10 \%$ recommended dose of $\mathrm{N}(31.83 \mathrm{~cm})$, and the lowest plant height $(25.68 \mathrm{~cm})$ was recorded from farmers' practices (Table 3). Hussain et. al. (2010) reported that plant height of cabbage was significantly influenced by USG application.

\section{Periphery of the head (cm)}

In 2007-08, the highest periphery $(69.73 \mathrm{~cm})$ of cabbage head was found with the recommended $\mathrm{N}$ dose used as USG followed by USG $<10 \%$ recommended dose of $\mathrm{N}$. The lowest plant height $(61.73 \mathrm{~cm})$ was recorded from farmers' practices. On the contrary in 2008-09, the highest periphery (68.47 $\mathrm{cm}$ ) of cabbage head was gained with the recommended $\mathrm{N}$ dose applied as USG that was statistically different to that of USG $<10 \%$ recommended dose of $\mathrm{N}(66.69 \mathrm{~cm})$ and the lowest plant height $(61.35 \mathrm{~cm})$ was recorded from farmers' practice (Table 3 ). The findings are in agreement with Hossain et al. (2010).

\section{Head diameter of cabbage (cm)}

The highest head diameter of cabbage $(23.63 \mathrm{~cm})$ was recorded from the recommended USG dose, while in recommended dose of $\mathrm{N}$ used as PU produced the lowest $(18.92 \mathrm{~cm}$ ) head diameter (Table 3).

\section{Number of outer leaves plant ${ }^{-1}$}

In 2007-08, the highest number of outer leaves plant ${ }^{-1}$ (13.67) was observed with the recommended $\mathrm{N}$ dose used as PU and the lowest outer leaves plant ${ }^{-1}$ (10.66) was obtained from USG $(20 \%<$ recommended dose $)$. The highest number of outer leaves plant ${ }^{-1}$ (12.67) was recorded with the recommended $\mathrm{N}$ dose used PU in 2008-09, while in recommended dose of $\mathrm{N}$ used as USG $(10 \%$ recommended) and USG $(20 \%$ < recommended) produced the lowest number of outer leaves plant ${ }^{-1}$ (10.33) of cabbage (Table 4).

\section{Head weight (kg)}

Table 4 shows that the highest individual head weight of cabbage ( 3.05 and $3.04 \mathrm{~kg}$ ) was recorded in the recommended dose of $\mathrm{N}$ applied as USG during the year 2007-08 and 2008-09, respectively. The lowest individual head weight of cabbage (2.06 and $2.09 \mathrm{~kg})$ was found from farmers' practice for both the years, respectively.

\section{Head yield $\left(\boldsymbol{t} \mathrm{ha}^{-1}\right)$}

The highest head yield of cabbage was found from USG recommended dose (92.04 and $91.36 \mathrm{t} \mathrm{ha}^{-1}$ ) from the year 2007-08 and 2008-09, respectively which was statistically identical with USG $10 \%$ less then recommended dose (84.78 and $84.40 \mathrm{t} \mathrm{ha}^{-1}$ ) followed by USG $20 \%$ less than recommended dose (79.51 and $78.18 \mathrm{t} \mathrm{ha}^{-1}$ ). This was happened due to the vigorous plant growth, higher periphery of the head $(\mathrm{cm})$, head diameter $(\mathrm{cm})$ those ultimately yielded higher head weight $(\mathrm{kg})$ (Table 4). Nazrul et al. (2006 and 2007) reported that the average yield of cabbage is much higher by using USG than that of PU. Hossain et al. (2010) also reported that yield of cabbage significantly influenced by USG. The other reason of higher yield was due to minimum loss of nitrogen by leaching and volatilization is minimal in USG (Muneshwar et al., 1992). Therefore, head yield of cabbage was increased significantly due to application of USG over PU.

\section{Cost and return analysis}

Analysis of cost and return revealed that the highest gross return (TK. $366800 \mathrm{ha}^{-1}$ ) and gross margin (TK. $288150 \mathrm{ha}^{-1}$ ) were obtained in $\mathrm{T}_{2}$ treatment (Table 5). The highest BCR (4.66) was recorded for the recommended dose of $\mathrm{N}$ applied as USG followed by $10 \%$ and $20 \%$ less than recommended dose of $\mathrm{N}$ used as USG (4.46 and 4.29, respectively). The similar trends of cost and return of cabbage cultivation in Tangail region was also reported by Nazrul et al. (2007). The lowest gross return (TK. $251120 \mathrm{ha}^{-1}$ ) and gross margin (TK.175400 ha-1) were gained by farmers practice $\left(\mathrm{T}_{4}\right)$ that also gave the lowest BCR (3.35) (Table 5).Therefore, using USG instead of traditional PU could save 10-20\% nitrogenous fertilizer and could be profitable for cabbage cultivation. 
Table 3. Effect of different form of urea on plant height, periphery of the head, and head diameter of cabbage

\begin{tabular}{|c|c|c|c|c|c|c|}
\hline Treatments* & \multicolumn{2}{|l|}{ Plant height (cm) } & \multicolumn{2}{l|}{ Periphery of the head (cm) } & \multicolumn{2}{l|}{ Head diameter (cm) } \\
\cline { 2 - 7 } & $2007-08$ & $2008-09$ & $2007-08$ & $2008-09$ & $2007-08$ & $2008-09$ \\
\hline $\mathrm{T}_{1}$ & $\mathbf{2 8 . 7 9 c d}$ & $27.55 \mathrm{c}$ & $\mathbf{6 4 . 9 3}$ & $63.64 \mathrm{c}$ & $\mathbf{2 0 . 1 7 d}$ & $19.64 \mathrm{~d}$ \\
\hline $\mathrm{T}_{2}$ & $\mathbf{3 5 . 0 1 a}$ & $33.76 \mathrm{a}$ & $\mathbf{6 9 . 7 3 a}$ & $68.47 \mathrm{a}$ & $\mathbf{2 4 . 7 7 a}$ & $23.63 \mathrm{a}$ \\
\hline $\mathrm{T}_{3}$ & $\mathbf{3 2 . 8 4 a b}$ & $31.83 \mathrm{~b}$ & $\mathbf{6 7 . 7 0 b}$ & $66.62 \mathrm{~b}$ & $\mathbf{2 3 . 2 6 b}$ & $22.30 \mathrm{~b}$ \\
\hline $\mathrm{T}_{4}$ & $\mathbf{3 0 . 9 4 b c}$ & $30.83 \mathrm{~b}$ & $\mathbf{6 5 . 7 0 c}$ & $64.35 \mathrm{c}$ & $\mathbf{2 1 . 9 7 c}$ & $21.03 \mathrm{c}$ \\
\hline $\mathrm{T}_{5}$ & $\mathbf{2 7 . 0 3 d}$ & $25.68 \mathrm{~d}$ & $\mathbf{6 1 . 7 3 d}$ & $61.35 \mathrm{~d}$ & $\mathbf{1 9 . 3 7 d}$ & $18.92 \mathrm{~d}$ \\
\hline CV \% & $\mathbf{7 . 7 8}$ & 2.56 & $\mathbf{5 . 1 2}$ & 0.86 & $\mathbf{8 . 2 3}$ & 3.15 \\
\hline
\end{tabular}

$* \mathrm{~T}_{1}$ : recommended $\mathrm{N}$ dose as PU, $\mathrm{T}_{2}$ : recommended $\mathrm{N}$ dose as USG, $\mathrm{T}_{3}: 10 \%$ less than recommended dose of $\mathrm{N}$ as USG, $\mathrm{T}_{4}: 20 \%$ less than recommended dose of $\mathrm{N}$ as USG, and $\mathrm{T}_{5}$ : Farmers practices (average of 20 farmers $\mathrm{N}$ dose used as PU)

Table 4. Effect of different form of urea on outer leaves plant ${ }^{-1}$, head weight and head yield of cabbage

\begin{tabular}{|c|c|c|c|c|c|c|}
\hline \multirow{2}{*}{ Treatments* $^{*}$} & \multicolumn{2}{|c|}{ Outer leaves/plant (Nos.) } & \multicolumn{2}{c|}{ Head weight $\mathbf{( k g})$} & \multicolumn{2}{c|}{ Head yield (t ha } \\
\cline { 2 - 7 } & $2007-08$ & $2008-09$ & $2007-08$ & $2008-09$ & $2007-08$ & $2008-09$ \\
\hline $\mathrm{T}_{1}$ & $\mathbf{1 3 . 6 7 a}$ & $12.67 \mathrm{a}$ & $\mathbf{2 . 2 8}$ & $2.31 \mathrm{c}$ & $\mathbf{7 0 . 4 9 c}$ & $70.14 \mathrm{c}$ \\
\hline $\mathrm{T}_{2}$ & $\mathbf{1 2 . 3 3 b c}$ & $11.33 \mathrm{ab}$ & $\mathbf{3 . 0 5 a}$ & $3.04 \mathrm{c}$ & $\mathbf{9 2 . 0 4 a}$ & $91.36 \mathrm{a}$ \\
\hline $\mathrm{T}_{3}$ & $\mathbf{1 1 . 3 2 c d}$ & $10.33 \mathrm{~b}$ & $\mathbf{2 . 8 0 a b}$ & $2.80 \mathrm{ab}$ & $\mathbf{8 4 . 7 8 a b}$ & $84.4 \mathrm{ab}$ \\
\hline $\mathrm{T}_{4}$ & $\mathbf{1 0 . 6 6 d}$ & $10.33 \mathrm{~b}$ & $\mathbf{2 . 6 3 b}$ & $2.65 \mathrm{~b}$ & $\mathbf{7 9 . 5 1 b}$ & $78.18 \mathrm{~b}$ \\
\hline $\mathrm{T}_{5}$ & $\mathbf{1 3 . 0 0 a b}$ & $12.33 \mathrm{a}$ & $\mathbf{2 . 0 6 c}$ & $2.09 \mathrm{c}$ & $\mathbf{6 3 . 0 7 c}$ & $62.5 \mathrm{~d}$ \\
\hline CV \% & $\mathbf{7 . 3 6}$ & 6.31 & $\mathbf{8 . 5 6}$ & 5.54 & $\mathbf{1 0 . 0 6}$ & 4.93 \\
\hline
\end{tabular}

* $\mathrm{T}_{1}$ : recommended $\mathrm{N}$ dose as PU, $\mathrm{T}_{2}$ : recommended $\mathrm{N}$ dose as USG, $\mathrm{T}_{3}: 10 \%$ less than recommended dose of $\mathrm{N}$ as USG, $\mathrm{T}_{4}: 20 \%$ less than recommended dose of $\mathrm{N}$ as USG, and $\mathrm{T}_{5}$ : Farmers practices (average of 20 farmers $\mathrm{N}$ dose used as PU)

Table 5. Benefit-Cost Ratio analysis of cabbage influenced by USG (average of two years)

\begin{tabular}{|c|c|c|c|c|c|}
\hline Treatments* & $\begin{array}{c}\text { Yield } \\
\left(\mathrm{t} \mathrm{ha}^{-1}\right)\end{array}$ & $\begin{array}{c}\text { Gross return } \\
\left(\text { Tk ha }^{-1}\right)\end{array}$ & $\begin{array}{c}\text { TVC } \\
\left(\mathrm{TK} \mathrm{ha}^{-1}\right)\end{array}$ & $\begin{array}{c}\text { Gross margin }(\mathrm{Tk} \\
\left.\text { ha }^{-1}\right)\end{array}$ & BCR \\
\hline $\mathrm{T}_{1}$ & 70.32 & 281280 & 77550 & 203730 & 3.63 \\
\hline $\mathrm{T}_{2}$ & 91.70 & 366800 & 78650 & 288150 & 4.66 \\
\hline $\mathrm{T}_{3}$ & 84.41 & 337640 & 75750 & 261890 & 4.46 \\
\hline $\mathrm{T}_{4}$ & 78.85 & 315400 & 73512 & 241888 & 4.29 \\
\hline $\mathrm{T}_{5}$ & 62.78 & 251120 & 75720 & 175400 & 3.32 \\
\hline
\end{tabular}

$* \mathrm{~T}_{1}$ : recommended $\mathrm{N}$ dose as PU, $\mathrm{T}_{2}$ : recommended $\mathrm{N}$ dose as USG, $\mathrm{T}_{3}: 10 \%$ less than recommended dose of $\mathrm{N}$ as USG, $\mathrm{T}_{4}: 20 \%$ less than recommended dose of $\mathrm{N}$ as USG, and $\mathrm{T}_{5}$ : Farmers practices (average of 20 farmers $\mathrm{N}$ dose used as PU)

N.B: Market Price $\left(\mathrm{Tk}_{\mathrm{Kg}}{ }^{-1}\right)$ : Cow dung = 1, Urea=12, TSP=22, MoP=15, Gypsam= 140, Zinc Sulphate = $130 \mathrm{Tk}$, Boron=180, Seedling $=50 \mathrm{tk} / 100$ nos., Labour $=180 / \mathrm{MD}^{-1}$ and Cabbage $=4$ 


\section{Conclusions}

The two years mean results revealed that the highest yield $\left(91.70 \mathrm{t} \mathrm{h}^{-1}\right)$, highest gross return (Tk.366800) and highest BCR (4.66) were found with the recommended $\mathrm{N}$ dose used as USG. Therefore it could be concluded that use of all the rate of $\mathrm{N}$ used as USG showed better performance than normal PU for cabbage yield and found to be economically viable. However, it is also clear that there were no significant differences between the treatments of recommended $\mathrm{N}$ dose used as USG and USG 10\% less than recommended $\mathrm{N}$ dose regarding yield and economic return. The rate of $\mathrm{N}$ dose $128-160 \mathrm{~kg} \mathrm{ha}^{-1}$ applied as USG may be recommended for the cultivation of cabbage in the medium highland of Sylhet (AEZ-20). The co-operator farmers were observed to be very happy with the higher yield of cabbage by USG application and opined that USG is more effective and profitable than that of normal PU. They expressed their interest to apply USG for cabbage cultivation.

\section{References}

BARC (Bangladesh Agricultural Research Council). 2005. Fertilizer Recommendation Guide- 2005. Published by BARC, Farmgate, Dhaka.

Bhuiyan, N.I., Saleque, M.A. and Panaullah, G.M. 1991. Nitrogen fertilizer management for higher efficiency in wetland rice. Bangladesh J. Soil Sci., 21: 29-39.

BRRI. 1988. Annual Report for 1986. Bangladesh Rice research Institute. Gazipur, Bangladesh. Publication no. 88:71.

Crasswell, E.T. and Datta, S. K. De. 1980. Recent development in research on nitrogen fertilizers for rice. International Rice research Institute, Los Banos, Laguna, Philippines. Res. Paper series no. 49. pp.1-11.

De Datta, S. K. and Crasswell, E. T. 1982. Nitrogen fertilizer management in wetland rice soils. In Int'l Rice Res. Inst. Rice Research Strategies for the Future. Los Banos, Philippines, pp: 283-316

Eusuf, H. M., Quayum, M.A., Razzaq, A., Alam, M.S., Jabber, M.A. and Quayyum, A. 1993. Economic analysis of urea super granules application in irrigated rice. Bangladesh Rice J., 4: $23-27$
Eusuf, H.M., Rashid, M. A., Azmal, A.K.M., Mazid, M. A. and Jabber, M.A. 1995. A comparative study of urea super granular and prilled urea application in irrigated rice. Bangladesh Rice J., 6: $13-16$

Gomez K.A. and Gomez, A.A. 1994. Statistical procedures for Agricultural Research ( $3^{\text {rd }} \mathrm{Edn}$.), John Wiley @ Sons, New York. 680p

Hussain, M.J., Ali, M.Y., Rahman, M.A., Quayyum, M.A. and Choudhury, D.A. 2010. Effect of urea super granule on the performance of cabbage in young jomuna and bramaputra floodplain soils of Tangail. Bangladesh J. Agril. Res. 35(2): 267272.

Muneshwar, S.P.N., Takkar, Vi Ben., Choudhury, M.R.., Sidhu, P.S., Pashricha, N.S. and Bajwa, M.S. 1992. Proceedings of International Symposium on Nutrient Management for Sustained Productivity, 2:7-8

Nazrul, M.I., M.A. Rahman., D.A. Choudhury and M.A. Quayyum. 2007. Effect of different time and depths of USG application on growth and yield of cabbage. Bangladesh J. Agril. Res., 32(2): 301-306.

Nazrul, M.I., Rahman, M.A., Choudhury, D.A. and Quayyum, M.A. 2007. Effect of urea super granule na prilled urea in performance of banana. Bangladesh J. Agril. Res., 32(1): 145-149.

Nazrul, M.I., Hossain, M.J. Ali, M.Y. and Shahmim, R.U. 2006. Use of Urea Super Granule (USG) in vegetables cultivation: A profitable technology (Booklet). Published by Bangladesh Agricultural Research Institute, Gazipur. 8p.

Rahman, M. A., Akanda, M.H., Rahman, M.M. and Ali, M.Y. 2004. Effect of Urea Super Granule and prilled urea application on agro-economic performance of potato. J. Agric. Edu. Technol., 6(1\&2): $17-20$

Savant, N.K., Dhane, S.S. and Talashilkar, S. 1991. Fertilizer News. International Fertilizer Development Centre, Muscle holas, Albama and I.S.A. 36(3): 19-25.

Zaman, S.K., Razzaque, M. A., Karim, S.M.R and Ahmed, A.U. 1993. Evaluation of prilled urea and urea super granule as nitrogen sources for upland aus rice. Bangladesh Rice J., 4: 412-46 